\title{
九州下フィリピン海スラブの形状と地震活動
}

\author{
福岡管区気象台* 石 原 和 彦 \\ 気象研究所** 吉 田 明夫

\section{Configuration of the Philippine Sea Slab and Seismic Activity in and around Kyushu}

\author{
Kazuhiko IsHiHaRA \\ Fukuoka District Meteorological Observatory, 1-2-36, Ohori, Chuo-ku, Fukuoka 810, Japan \\ and Akio Yoshida
}

Meteorological Research Institute, 1-1, Nagamine, Tsukuba, Ibaraki 305, Japan

(Received June 14, 1991; Accepted April 17, 1992)

\begin{abstract}
There are several gap zones in the intermediate-depth seismicity in the Philippine Sea slab beneath Kyushu. The focal depth of the deepest earthquake increases step-like toward the south, and dip direction and inclination of the slab change from segment to segment divided by the gaps. Further, seismicity around the depth of $80 \mathrm{~km}$, where the slab bends steeply downwards, varies with the segments. That is, the seismicity is very low for the northern segment, whereas fairly many earthquakes occur in the middle and the southern segments, although no earthquake with $M \geqq 4$ was observed in the depth range deeper than $80 \mathrm{~km}$ in the southern segment during the period 1926 through 1990. Sectionalization is seen in the seismic activities in the Hyuganada basin. Aftershock areas of large earthquakes in the Hyuganada basin are delineated by the boundaries of the segments. Moreover, a tendency of successive occurrence of large earthquakes, first in the northern section, then in the southern section, is clearly recognized.
\end{abstract}

Key words: Kyushu, Philippine Sea slab, Segmentation, Hyuganada Basin, Successive occurrence.

\section{§1.はじめに}

九州下におけるフィリピン海スラブ内のサイスミシ ティやスラブの形状に関しては, これまでに多くの研究 がある [例えば SHiono et al. (1980), IMAGAwA et al. (1985), 石川 (1985), 高橋 (1987), 高橋・他 (1987), 長 宗・田代 (1989), 角田・他 (1991)]。これらの研究に よって, 九州下ではスラブの到達深度が北から南にいく につれて次第に深くなること，深さ 70〜80 km 付近で 地震面は大きく折れ曲がって, それ以深では沈み込み角 度がほぼ $70^{\circ}$ と急傾斜になることが明らかにされ，スラ ブ折れ曲がり付近のサイスミシティが著しく低いこと, それより下部の稍深発地震の発震機構から求まる最大主 圧力軸は水平方向であることなどが指摘されている [例

* \%810 福岡市中央区大溕 1-2-36

** 个305 茨城県つくば市長峰 1-1
えば, Shiono et al. (1980), Imagawa et al. (1985)].ま た, 長宗・田代 (1989) は 1983 年 1 月〜 1987 年 4 月の 気象庁震源データを解析し, 地震面の厚さや傾斜角, 最 深部の深さなどの差異に基づいて，九州下のスラブに 2 か所の断裂を推定した.

九州地方における気象庁の震源決定能力は， 1984 年 に地震観測網のテレメータ化が完成して以後大幅に向上 した [山本 (1985)]。本論文では, 1984 年 1 月 1990 年 12 月の気象庁震源データを用い, スラブの断裂の存 在に焦点をしぼって, 稍深発地震活動並びに日向灘の地 震活動の地域的特徵について検討する.

\section{§2. 九州下のフィリピン海スラブ}

Fig. 1 は, 九州下における $70 \mathrm{~km}$ 以深の地震の震央 分布と, $\mathrm{N} 153^{\circ} \mathrm{W}-\mathrm{N} 27^{\circ} \mathrm{E}$ 方向に切った震源の断面を示 したものである.この断面図から, 図中の $\mathrm{A} \sim \mathrm{E}$ のとこ 

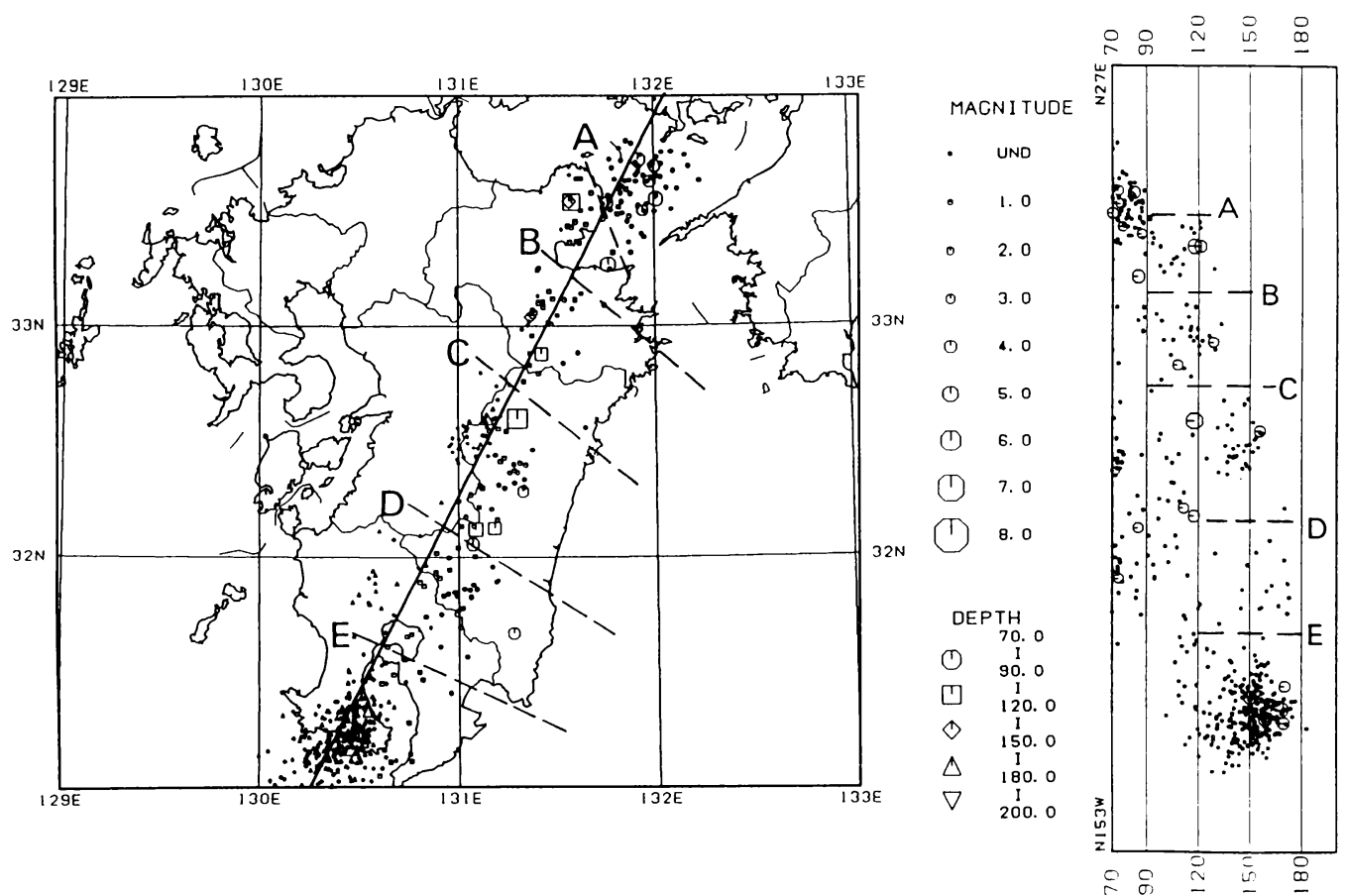

Fig. 1. Epicentral distribution (left) and cross section in the direction of $\mathrm{N} 27^{\circ} \mathrm{E}$ (right) for earthquakes with focal depth $\geqq 70 \mathrm{~km}$ during the period 1984-1990. Gap zones in the intermediate-depth seismicity are indicated by $\mathrm{A}, \mathrm{B}, \mathrm{C}, \mathrm{D}$ and $\mathrm{E}$.

ろでサイスミシティが低く，またそこを境に震源の最深 部は南側にいくにつれてステップ状に深くなっているこ とがわかる. 長宗・田代 (1989) は, 同様な稍深発地震の サイスミシティとその震源断面図から, 稍深発地震が群 れになって発生している領域の北端, ほぼ C と E に相 当するところに, スラブの断裂の存在を想定している. 一方, 角田・他 (1991) は稍深発地震活動の空白域と大 規模カルデラとの位置的対応に着目し, 地表の地質構造 線も考慮に入れて，むしろそれらの空白域のところが稍 深発地震面のブロック構造境界を表すと考えている.

Fig. 1 の震源断面図からは, 先に述べたように, 長宗・ 田代 (1989) や角田・他 (1991) が指摘した C, E 以外に, A， B，D のところにも稍深発地震活動の低い領域が認め られる．以下では， B と C の間をセグメント I， C と D の間をセグメント II, D と $\mathrm{E}$ の間をセグメント III とし て, 地震活動や震源分布について各セグメント間での差 違を検討する. なお，伊予灘付近及び $\mathrm{E}$ の南側領域の地 震活動に関しては別稿で論じる.

ところで, Fig. 1 に見るように, スラブ内地震活動が 低く, 地震の深さが变わるという条件だけからでは, 断 裂の位置に不確定さが生じる. 実際, 長宗・田代 (1989) と角田・他 (1991) では推定された断裂の場所が多少
違っている. その意味でFig. 1 の A〜E の線も, 現段階 ではセグメントへの区分けの一つの目安と見るべきもの である.

Fig. 2 にそれぞれのセグメントについて $\mathrm{N} 63^{\circ} \mathrm{W}$ 方向 に切った断面図を示す，スラブの到達深度は I， II， III の順に，約 $130 \mathrm{~km}, 160 \mathrm{~km}$ ，そして $180 \mathrm{~km}$ と深く なっている. また, $80 \mathrm{~km}$ 付近の地震面の折れ曲がりの 角度とその近傍のサイスミシティに，各セグメント間で 違いが見られる. Shiono et al. (1980) は 1964 1975 年の ISC データを, また IMAGAWA et al. (1985) は 1961 〜1983 年の気象庁データを解析して，九州下スラブの 折れ曲がり付近のサイスミシティがきわめて低いことを 指摘した. しかし，Fig. 2 の断面図，及び Fig. 3(c)のス ラブの折れ曲がり付近に相当する深さの地震活動を見る と, セグメントIでは確かに折れ曲がり付近のサイスミ シティは低いが， II，III ではかなりの数の地震が起きて いることがわかる.ただし，M4 以上の地震に限ると, セグメント IIIでは $80 \mathrm{~km}$ 以深に全く見られない.これ に対してセグメントIIでは $80 \mathrm{~km}$ 以深にも多くの $M 4$ 以上の地震が発生している.これらは 1984〜1990 年の 期間の震源デー夕に基づいたものであるが, 稍深発地震 活動に関する上の特徵は，1926～1990 年の長期間震源 

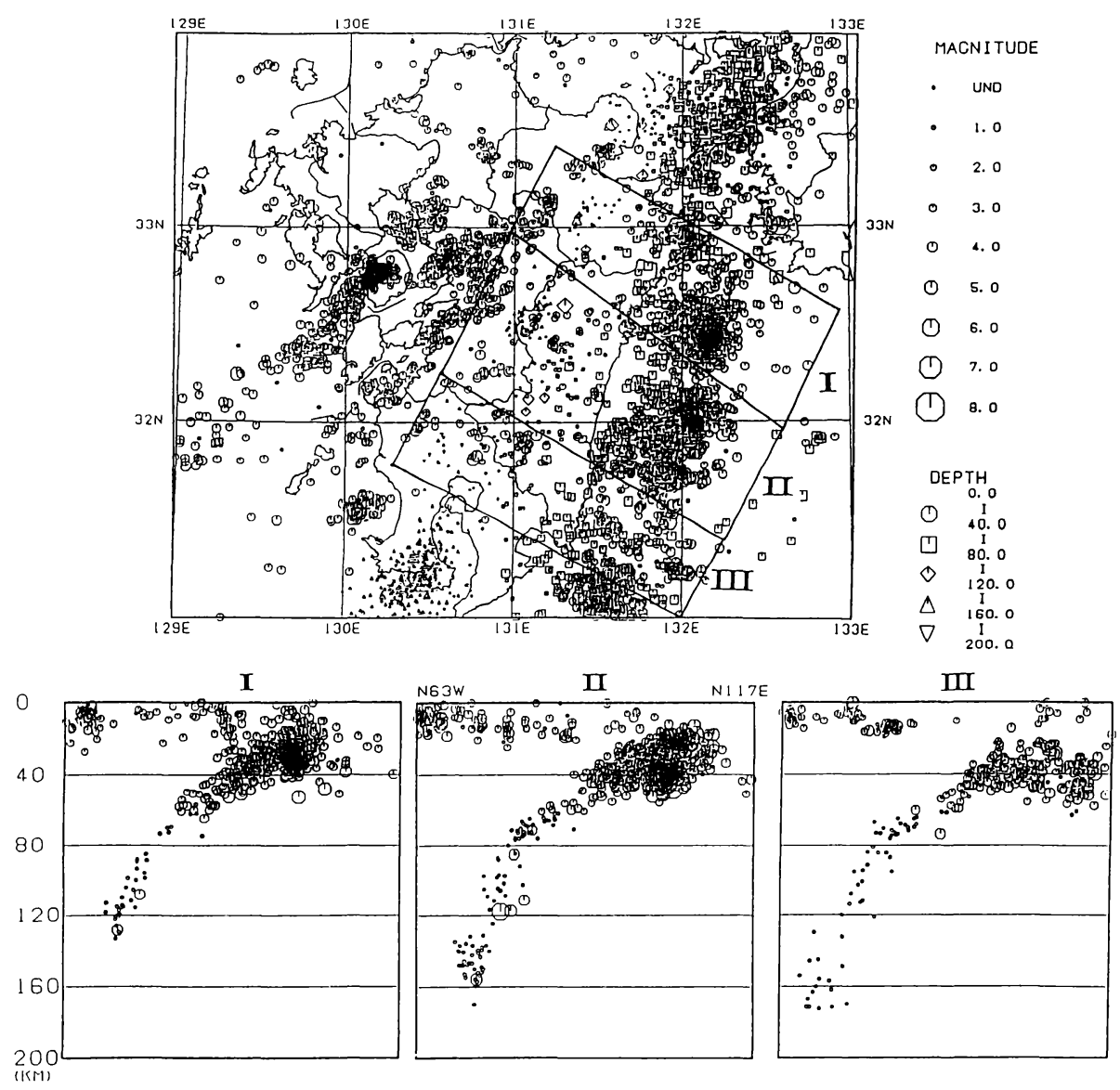

Fig. 2. Cross sections of the hypocentral distribution of earthquakes in each segment I, II and III shown in the epicentral map. Note the difference of seismicities around the kink of the slab-it is very low in the segment I, whereas a fairly many earthquakes are observed in the segments II and III, although there is no earthquake with $M \geqq 4$, depth $\geqq 80 \mathrm{~km}$ in the segment III.

データにおいても共通して見ることができる.

なお，折れ曲がりの角度は，セグメント I， II に比べ てセグメントIIIでは緩やかになっている。 そのことは,

例えば, Fig. 2 の断面図で, 日向灘のプレート間カップ リング領域からサイスミックゾーンの同じ深さのところ までの水平距離の違いに表れている.

次に深さ別にサイスミシティの特徴を見てみる．まず 深さ $20 \mathrm{~km}$ から $40 \mathrm{~km}$ までの地震活動の震央分布 [Fig. 3(a)] からは, 先に想定したスラブの切れ目のとこ ろで, 日向灘の地震活動むブロック化されている様子が 見られる. スラブの折れ曲がり部分に相当する深さ 70 $\mathrm{km}$ 前後の地震活動 [Fig. 3(c)] の地域性については先に 述べた．沈み込み角度が急となってからの，80〜160 $\mathrm{km}$ の深さの地震の震央分布の西縁を点線で示した Fig. 3(d), (e) からは, スラブの最大傾斜方向はセグメント I から正へ順に， それぞれ約 $\mathrm{N} 70^{\circ} \mathrm{W}, \mathrm{N} 65^{\circ} \mathrm{W}, \mathrm{N} 60^{\circ} \mathrm{W}$
と, 南にいくにつれて次第に北向きに変わっている様子 が見られる. また, $160 \mathrm{~km}$ 以深の地震の発生は $\mathrm{D}$ より 南側に限られる [Fig. 3(f)].

以上の事実は, 九州下のフィリピン海プレートがいく つかのセグメントに分かれているという仮説を支持する あのである.

\section{§3. スラブのセグメンテーションと日向潅の地震活 動}

先に, 日向灘では $\mathrm{B}, \mathrm{C}$ の延長を境界とする地震活動 のブロック化が見られることを指摘した [Fig. 3(a)]. こ うした特徵は日向灘に発生する大地震の震源域に明瞭に 現れている. 例えば，Cの北側に震源を有する 1984 年 8 月 7 日の $M 7.1$ の地震, 及びそれに引き続いて C の南 側で発生した 1987 年 3 月 18 日の $M 6.6$ の地震後の, それぞれ一ヶ月間の地震活動を見ると [Fig. 4(a)], 余震 
(a)

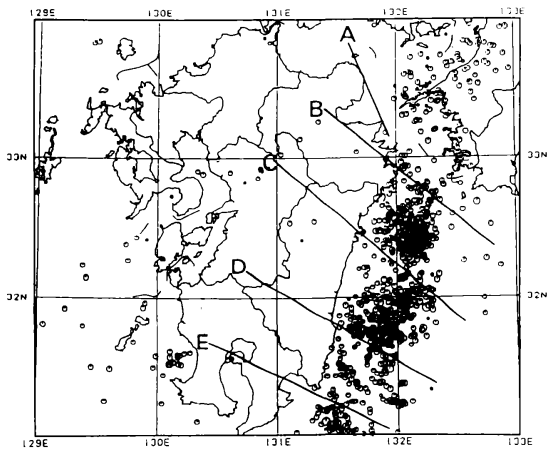

(b)
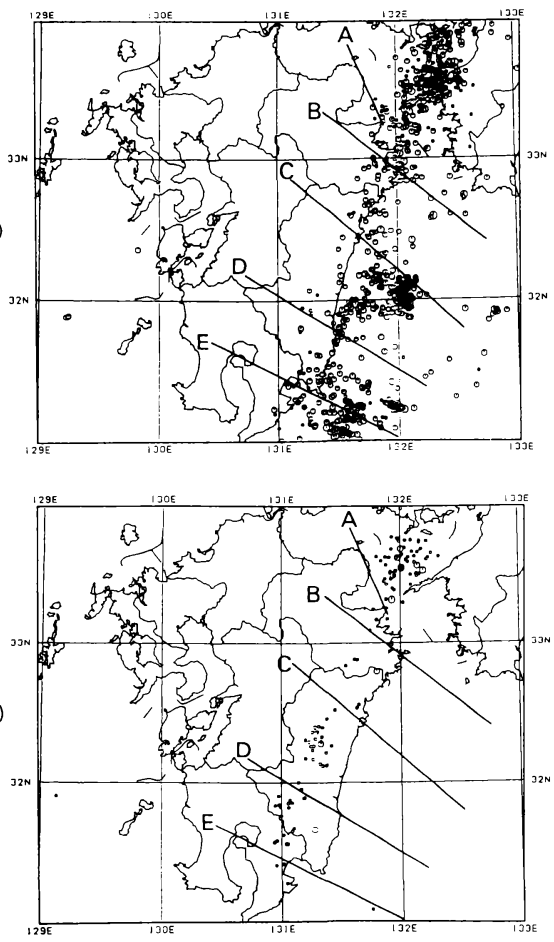

MACNI TUDE

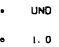

2.0

- 3.0

- 4. 0

- 5. 0

( 6.0

(1) 7.0

(1) 0

DEPTH
60.0
64.9
1.

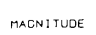

- unO

- 1.0

- 2.0

0.0
0.0

5.0

- 6.0

(1) 7.0

(1) 8.0

$\begin{array}{r}\text { DEPTH } \\ 65.0 \\ 0 \quad 19.9 \\ \hline \quad 7.9\end{array}$ (d)
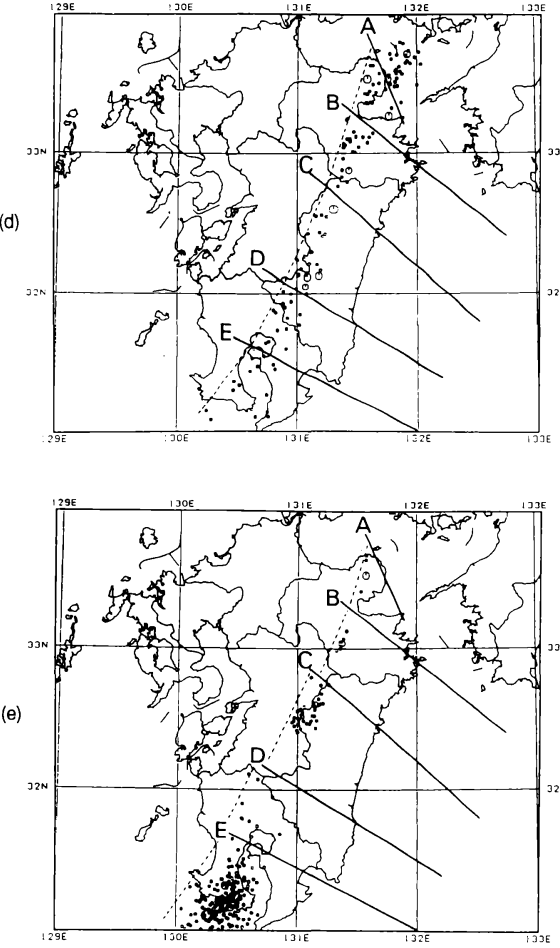

MACNI TUDE

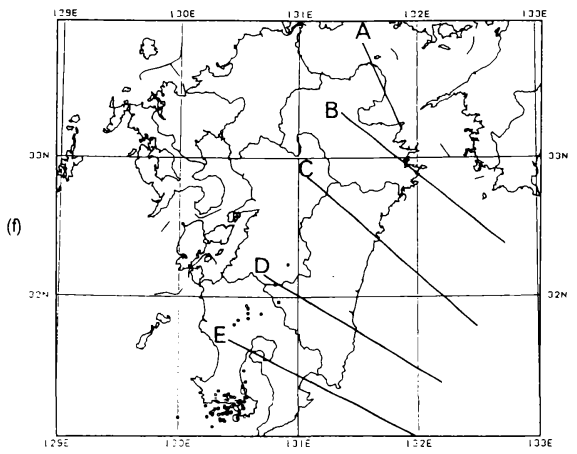

MACNI TUDE

Fig. 3. Epicentral distribution of earthquakes in different depth ranges: (a) $20 \mathrm{~km} \leqq$ depth $<40 \mathrm{~km}$, (b) 40 $\mathrm{km} \leqq$ depth $<65 \mathrm{~km}$, (c) $65 \mathrm{~km} \leqq$ depth $<80 \mathrm{~km}$, (d) $80 \mathrm{~km} \leqq$ depth $<120 \mathrm{~km}$, (e) $120 \mathrm{~km} \leqq$ depth $<160$ $\mathrm{km}$, (f) $160 \mathrm{~km} \leqq$ depth $\leqq 200 \mathrm{~km}$.

域は, 1984 年の地震では $\mathrm{C}$ の北側に，また 1987 年の 地震では C の南側にあったことは明らかである．同様 に, Fig. 4(b) は, 1968 年 4 月 1 日の $M 7.5$ の地震, 1969 年 4 月 21 日の $M 6.5$ の地震, 1970 年 7 月 26 日 の $M 6.7$ の地震の後, それぞれ一力月間の余震を重ねて プロットしたものであるが（震源データは地震月報別冊 第 6 号 [気象庁 (1982)] による. Fig. 4(c) も同様), 先の 例之同じく, 1968 年の地震の余震域は $\mathrm{C}$ の北側に, ま た 1969 年, 1970 年の地震の余震域は C の南側にあっ たことがわかる．さらに遡って，宇津のカタログ(1982)
によれば, 1931 年 11 月 2 日の $M 7.1$ の地震の震央は C の北側に, また 1941 年 11 月 19 日の $M 7.2$ の地震の 震央は C の南側にくる. Fig. 4(c) は 1939 年 3 月 20 日 の $M 6.5$ の地震, 及び 1941 年の地震の後の, それぞれ 一力月間の余震活動と, 宇津 (1982) による 1931 年の $M 7.1$ の地震の震央を重ねて示したものだが，これから 1941 年の地震の震源域は C の南側にあったこと, ま た，1939 年の地震の後，境界 C と B の近傍で地震活動 が活発だった様子が見られる，B と Cに沿っては，地震 の線状配列がこの期間以外にもしばしば認められる。な 

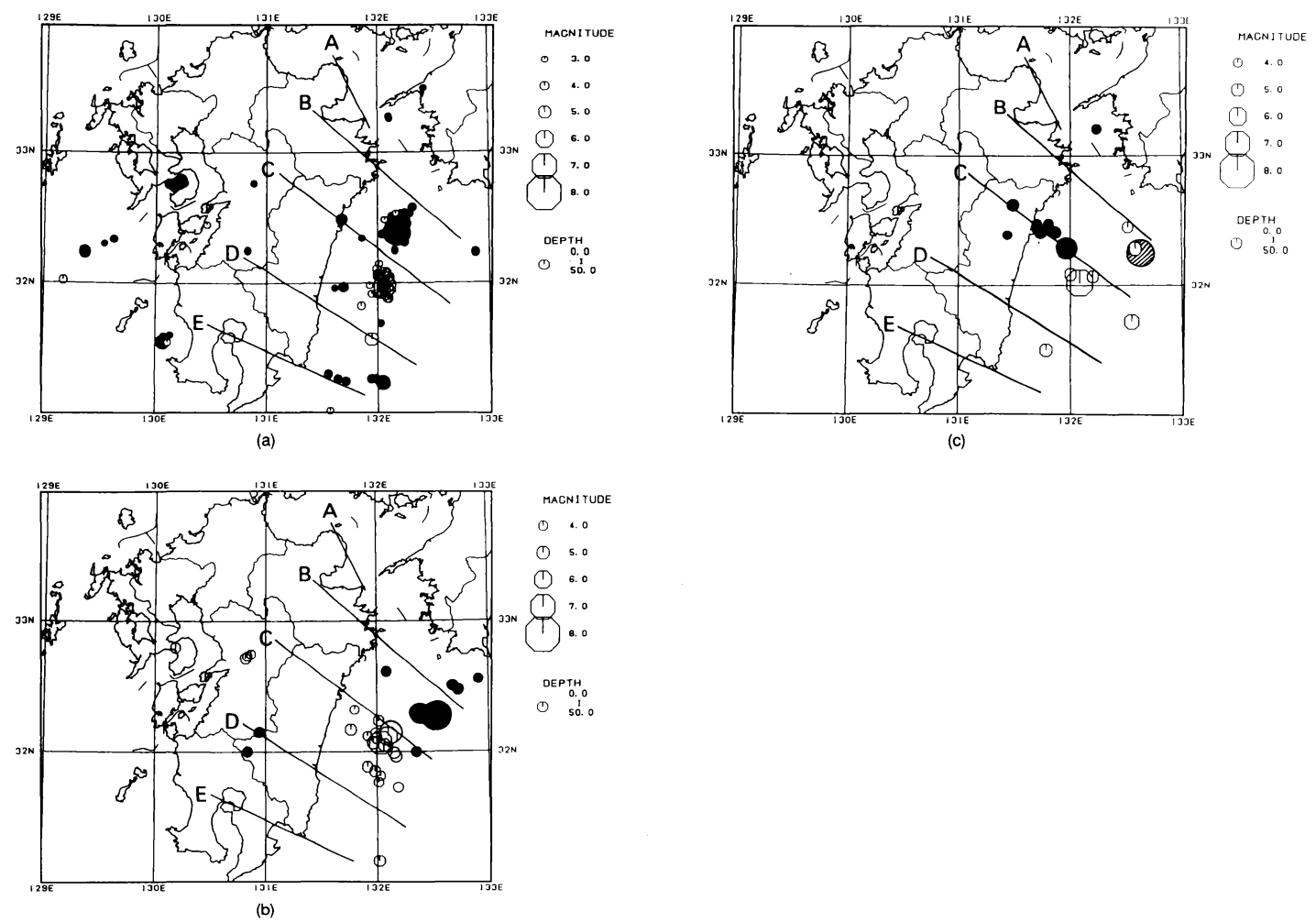

Fig. 4. (a) Superposition of epicentral distributions of earthquakes during each one month period just after the occurrence of an $M 7.1$ earthquake on 7 August 1984 (solid circles) and after an $M 6.6$ earthquake on 18 March 1987 (open circles).

(b) Superposition of epicentral distributions of earthquakes during each one month period just after the occurrence of an $M 7.5$ earthquake on 1 April 1968 (solid circles), after an $M 6.5$ earthquake on 21 April 1969 and an $M 6.7$ earthquake on 26 July 1970 (open circles).

(c) Superposition of epicentral distributions of earthquakes during each one month period after the occurrence of an $M 6.5$ earthquake on 20 March 1939 (solid circles) and after an $M 7.2$ earthquake on 19 November 1941 (open circles). A large circle with slant lines represents the epicenter of an $M 7.1$ earthquake on 2 November 1931.

お, 1931 年の $M 7.1$ の地震については, 震源域が C の 北と南の両側に及んでいたとする見解もある [長宗 (1988)].

以上の三つの例で注目すべき特徴は，C の北側でまず 大地震が発生して, 次いで C の南側でも発生するという パターンが共通して見られることである（上述のように 1931 年の地震については, 震源域が C の北と南の両側 に及んだ可能性がある).このような特徴は, 日向灘に発 生した $M 6.5$ 以上の地震の時空間分布からも明瞭であ る (Fig. 5). サブダクションゾーンの隣合ったカップリ ング領域において大地震が続いて発生するというパター ンは, 東南海地震と南海道地震の関係と似ていて興味深 い.

なお，UTSU (1974) は，日向灘の地震活動域を北から $\mathrm{U}, \mathrm{T}, \mathrm{V}$ の 3 つに分け, それぞれの領域の活動の特徴と
して, T では最大 $M 7.5$ に達する大地震がほぼ 30 年の 間隔で発生しているのに対して，Uでは高々 $M 7$ の地 震が群発する傾向が見られると述べている，U, T, V の 境界はほぼ C と D に対応する.

\section{§4. 議論}

南海トラフ沿いでは, 東南海地震や南海道地震のよう にM 8 クラスの巨大地震が発生するのに対して, 日向 灘では M 7.5 程度の地震が大きさの上限で, その代わり 地震発生の繰り返し間隔は短い。一般に相対運動速度が 同じであれば, カップリング領域の応力場の増大の仕方 は, その領域が小さいほど早くなるから [YoshidA (1980)]，これは九州下に沈み込むフィリピン海スラブが いくつかのセグメントに分かれているという仮説と合っ ている. また, 中国地方の内陸の地震活動は南海道地震 


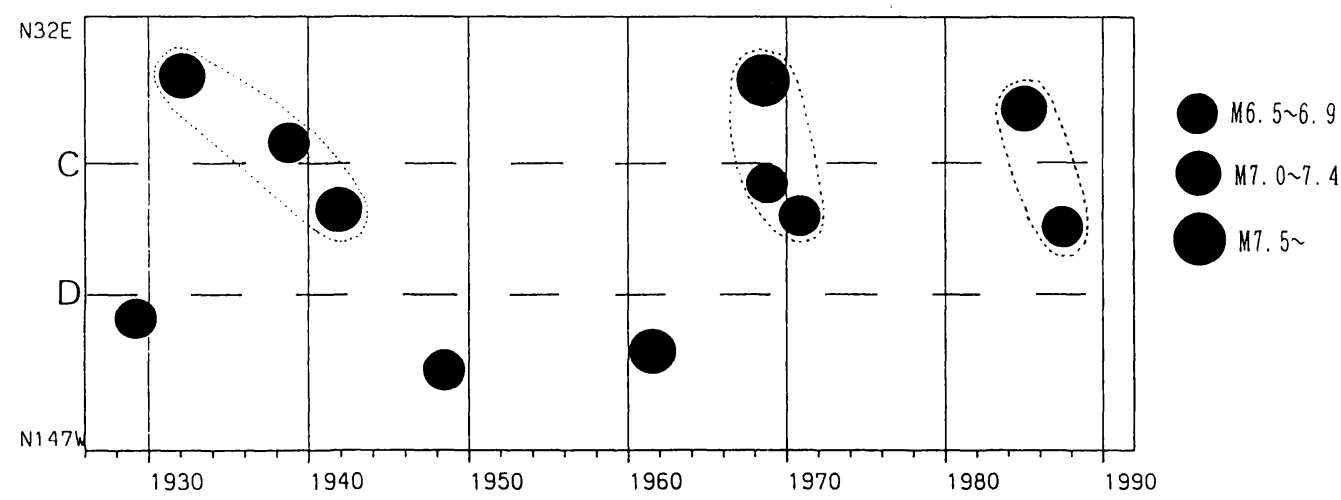

Fig. 5. Space-time distribution of earthquakes with $M \geqq 6.5$ occurring in the Hyuganada basin. It is clear that a large earthquake in the zone between $\mathrm{C}$ and $\mathrm{D}$ is likely to occur succeeding to the occurrence of a large earthquake in the zone between $\mathrm{B}$ and $\mathrm{C}$.

の発生が近づくと活発化する傾向がある [例えば MoGI (1981)] のに対して, 九州地方の浅発地震活動は日向灘 の大地震の前に特に活発化するようには見えない。この ことも，日向灘におけるプレート間カップリングは四国 沖に比べてスケールが小さなものであることを示唆す る.なお，九州中央部の浅い地震活動は，むしろ，フィ リピン海スラブ内の稍深発地震活動と相関を持つ [吉田 (1991)].

九州下のフィリピン海スラブが，その短さにもかかわ らず急角度で沈み込み，またセグメントに分かれている のは，九州中央部を西南西 - 東北東方向に横切って九州 を南北に分裂させつつある沖縄トラフ [多田 (1984), (1985)］の活動に起因する横方向の力を受けているため ではなかろうか. 更に, これに加えて，フィリピン海プ レート自体が変形しやすいということもあろう。伊豆半 島周辺や紀伊半島下であフィリピン海スラブは複雑な形 状をしており [石田 (1986), MizouE et al. (1983), 山 崎 -大井田 (1985), W ATANABE and MAEDA (1990)], こうした変形のしやすさは，スラブが比較的薄く，また 年代が若くて十分冷えきっていないことなども関係して いるものと思われる.

\section{§5. まとめ}

九州下スラブ内の稍潹発地震活動にはサイスミシティ の極度に低い部分が何か所かあって，そこを境にスラブ の到達深度はステップ状に南にいくにつれて深くなる。 そして，各セグメントによってスラブ折れ曲がり付近や それより深部のサイスミシティ, 最大傾斜方向に差違が 見られる.また，このような稍深発地震面のセグメン テーションは日向灘のプレート間カップリング領域の地 震活動のブロック的構造とも関係していて, 日向灘に発 生する大地震の震源域は, これらの境界の海側への延長
部で仕切られる. 以上のような特徵は, これらのセグメ ント境界がスラブの断裂を表しているという考え方を支 持する。なお，今世紀に日向灘で発生した $M 6.5$ 以上の 地震について見ると, まず境界 C の北側で大地震が起 き, 続いてその南側で大きな地震が発生するというパ ターンがほぼ共通して見られる。これは東南海地震と南 海道地震の関係に似ていて興味深い。

謝辞

鹿児島大学理学部角田寿喜教授及びもう一人の匿名の 查読者からの懇切なコメントは, 論文を改善するうえで たいへん有益であった，記して厚く感謝いたします。

\section{文献}

Imagawa, K., K. Hirahara and T. Mikumo, 1985, Source mechanisms of subcrustal and upper mantle earthquakes around the northeastern Kyushu region, southwestern Japan, and their tectonic implications, J. Phys. Earth, 33, 257-277.

石田端穂，1986, 関東・東海地域の震源分布加ら想定し たフィリピン海及び太平洋プレートの等深度線, 国立 防災科学技術センタ一研究報告, 36, 1-19.

石川有三, 1985 , 九州下の二重深発地震面, 地震 2,38 , 265-269.

角田寿喜 - 宮町宏樹 - 高木章雄, 1991, 九州 - 琉球孤北 部域の稍深発地震, 地震 $2,44,63-74$.

気象庁, 1982, 改訂日本付近の主要地震の表（1926 年 ～1960 年), 地震月報, 別冊第 6 号.

Mizoue, M., M. Nakamura, N. Seto and Y. Ishiketa, 1983, Three-layered distribution of microearthquakes in relation to focal mechanism variation in the Kii Peninsula, southwestern Honshu, Japan, Bull. Earthq. Res. Inst., Univ. Tokyo, 58, 287-310.

MogI, K., 1981, Seismicity in western Japan and longterm earthquake forecasting. In Simpson, D. W. 
and Richards P.G., eds., Maurice Ewing Series 4, Earthquake Prediction, Am. Geophys. Union, Washington D. C., 43-51.

長宗留男, 1988, 日向灘における大地震の活動, 鹿児島 大学理学部紀要, 第 21 号, 1-21.

長宗留男・田代秀樹, 1989, 九州下における和達一べニ オフゾーンの形状, 地震 2, 42, 13-19.

Shiono, K., T. Mikumo and Y. Ishik A w A, 1980, Tectonics of the Kyushu-Ryukyu arc as evidenced from seismicity and focal mechanisms of shallow to intermediate depth earthquakes, J. Phys. Earth, 28, 17-43.

多田 堯, 1984, 沖縄トラフの拡大と九州地方の地壳変 動, 地震 2, 37, 407-415.

多田 堯, 1985, 沖縄トラフと拡大と九州地方の地壳変 動 (2), 地震 $2,38,1-12$.

高橋道夫, 1987, 九州下の稍深発地震面の非二重性, 地 震 2, 40, 115-117.

高橋道夫・西辻和也・後藤主夫, 1987 , テレメータシス テムの整備により明らかになった九州地方の地震の特 徵, 気象庁研究時報, 39, 27-48.

UTSU, T., 1974, Space-time pattern of large earth- quakes occurring off the Pacific coast of the Japanese islands, J. Phys. Earth, 22, 325-342.

宇津徳治, 1982 , 日本付近の $M 6.0$ 以上の地震および被 害地震の表： 1885 年 1980 年, 地震研菓報, 57 , 401-463.

W atanabe, $H$. and N. Maeda, 1990, Seismic activity of subcrustal earthquakes and associated tectonic properties in the southwestern part of the Kinki district, southwestern Japan, J. Phys. Earth, 38, 325-345.

山本雅博・後藤主夫・豊田正昭・永岡 修, 1985, 福岡 管区気象台地震波形テレメータシステム整備とそれに 伴う地震検知能力の改善について, 験震時報, 49, 93104.

山崎文人・大井田 徹, 1985 , 中部地方におけるフィリ ピン海プレート沈み込みの形状, 地震 2, 38, 193-201.

Yoshida, A., 1980, Antidislocation as a source of earthquake, Pap. Meteorol. Geophys., 31, 7-14.

吉田明夫, 1991, 九州地方における稍深発地震活動と浅 発地震活動の相関とその地学的背景, 地学雑誌, 100 , $776-782$. 